\title{
UJI COBA DESAIN MEDIA BIOFILTER ANAEROB AEROB DALAM MENURUNKAN KADAR BOD, COD, TSS DAN COLIFORM LIMBAH CAIR RUMAH SAKIT
}

\author{
Tony Kurtis Timpua ${ }^{1)}$, Robinson Pianaung ${ }^{2)}$ \\ ${ }^{1,2)}$ Jurusan Kesehatan Lingkungan Poltekkes Kemenkes Manado \\ tonytimpua@gmail.com
}

\begin{abstract}
Besides providing health services, hospitals are also a source of producing liquid waste which has infectious, pathological and toxic properties, so that it can potentially transmit diseases to the community and pollute the surrounding environment. The processing of hospital wastewater is a serious problem because to make a Liquid Waste Treatment Plant that meets the requirements requires expensive fees. Therefore it is necessary to conduct research to find a simple but effective liquid waste treatment technology that reduces the level of liquid waste parameters, is easy to make, uses materials local, and is affordable. This study aims to determine the effectiveness of the design of aerobic anaerobic biofilter media in reducing levels of BOD, COD, TSS, and Coliform hospital wastewater, through an experimental method withTime Series Design. The results showed a decrease in BOD levels at a flow capacity of $301 / \mathrm{hr}$ detain time 6 hours (73.29\%), COD (76.94\%), TSS (76.60\%) and Coliform (83.87\%). Thus it was concluded that the design of aerobic anaerobic biofilter media with bottled mineral water media $330 \mathrm{ml}$ of flow capacity of 0.5 liters / minute detention time of 6 hours was more effective than bottled mineral water packaging media $600 \mathrm{ml}$ and $200 \mathrm{ml}$ mineral water packaging glass. It is recommended that further research is needed to determine the relationship of detention time, flow capacity to the effectiveness of biofiltration media.
\end{abstract}

Keywords: Design, media, biofilter, liquid waste, hospital

\begin{abstract}
Abstrak. Rumah Sakit selain menyelenggarakan pelayanan kesehatan, juga merupakan sumber penghasil limbah cair yang memiliki sifat infeksius, patologis dan beracun, sehingga berpotensi menularkan penyakit bagi masyarakat dan mencemari lingkungan sekitarnya. Pengolahan limbah cair rumah sakit menjadi masalah serius karena untuk membuat Instalasi Pengolahan Limbah Cair (IPLC) yang memenuhi syarat memerlukan biaya yang mahal. Oleh karena itu perlu dilakukan penelitian untuk menemukan teknologi pengolahan limbah cair yang sederhana tetapi efektif menurunkan kadar parameter limbah cair, mudah dibuat, menggunakan marterial lokal, dan harganya terjangkau. Penelitian ini bertujuan untuk mengetehui efektivitas desain media biofilter anaerob aerob dalam menurunkan kadar BOD, COD, TSS, dan Coliform limbah cair rumah sakit, melalui metode eksperimen dengan Rancangan Rangkaian Waktu (Time Series Design). Hasil penelitian menujukkan penurunan kadar BOD pada kapasitas aliran 30 1/jam waktu deteni 6 jam (73,29\%), COD (76,94\%), TSS (76,60\%) dan Coliform $(83,87 \%)$. Dengan demikian disimpulkan bahwa desain media biofilter anaerob aerob dengan media botol kemasan air mineral $330 \mathrm{ml}$ kapasitas aliran 0,5 liter/menit waktu detensi 6 jam lebih efektif dibandingkan dengan media botol kemasan air mineral $600 \mathrm{ml}$ dan gelas kemasan air mineral $200 \mathrm{ml}$. Untuk itu disarankan perlu penelitian lanjutan untuk mengetahui hubungan waktu detensi, kapasitas aliran terhadap efektifitas media biofiltrasi.
\end{abstract}

Kata Kunci: Desain, media, biofilter, limbah cair, rumah sakit

Limbah cair adalah semua air buangan termasuk tinja yang berasal dari kegiatan rumah sakit yang kemungkinan mengandung mikroorganisme, bahan kimia beracun dan radioaktif yang berbahaya bagi kesehatan (Permenkes RI. No. 1204, 2004). Volume limbah cair rumah sakit adalah $85-95 \%$ dari volume air bersih yang digunakan (Kepmenkes RI, No. 712 Tahun 1986). Persediaan air di rumah sakit adalah 500 liter/tempat tidur/hari. Ini berarti jumlah limbah cair dari kegiatan rumah sakit adalah berkisar antara $425-475$ $\mathrm{m}^{3}$ /hari (Permenkes RI No. 986 Tahun 1992). Limbah cair rumah sakit merupakan limbah yang membahayakan ekosistem lingkungan di sekitar rumah sakit dan bahkan lingkungan yang lebih luas. Limbah cair rumah sakit, umumnya berasal dari kegiatan-kegiatan seperti perawatan, bedah, laboratorium, poliklinik, farmasi, laundry, dapur, asrama dan kantor (Soejarwo 2003).

Tujuan utama pengolahan air limbah adalah untuk menurunkan BOD, partikel terlarut, menghilangkan nutrisi, bahan beracun, dan membunuh bakteri pathogen untuk melindungi lingkungan perairan dan mencegah penyebaran penyakit yang ditularkan melalui air limbah (Sugiharto, 1987).

$$
\text { Pengolahan biologis (sekunder) }
$$

bertujuan untuk menghilangkan bahan-bahan 
organik dan menurunkan BOD, menggunakan bantuan mikroorganisme seperti bakteri, fungi dan virus, yang ada dalam limbah cair. Apabila berlangsung baik pengolahan tersebut mampu menurunkan kadar BOD antara 90\% - 95\%. Dalam pengolahan biologis untuk air limbah, fungsi mikroorganisme tidak sebagai spesies yang berdiri sendiri, melainkan sebagai campuran dari berbagai jenis mikroorganisme yang membentuk sesuatu yang tetap tergantung pada sifat-sifat kondisi lingkungan mikroorganisme ketika bersaing untuk merebut makanan yang masuk (Sunu, 2001). Media biofiltrasi sangat menentukan bagi pertumbuhan mikroorganisme pengurai sehingga proses degradasi limbah cair oleh mikroba berlangsung optimal.

Organisme pengurai aerobik umumnya terdiri dari mikroorganisme seperti bakteri yang selalu bekerja dalam air menguraikan senyawasenyawa organik menjadi karbondioksida dan air. Proses-proses itu memerlukan oksigen, semuanya merupakan komponen daur biogeokimia dan esensial untuk fungsi ekosistem air (Sastrawijaya, 2000). Sel mikroba diperkirakan terdiri atas 50\% karbon, 5-15\% nitrogen, 0,5-1,5\% fosfor dan 0,5-1,5\% sulfur. Perbandingan $\mathrm{C}: \mathrm{N}: \mathrm{P}: \mathrm{S}$ adalah $100: 10: 1$ : 1. Untuk keperluan hidupnya mikroba memerlukan bahan-bahan atau nutrisi seperti tersebut di atas, digunakan dalam proses metabolisme menghasilkan energi yang dibutuhkan mikroba untuk pergerakan, reproduksi, pertahanan sel dan pertumbuhan (Muslimin, 1995). Bila bakteri berada pada lingkungan yang sesuai dan tersedia nutrisi dalam keadaan optimum, maka pertumbuhannya akan meningkat dalam waktu yang relatif singkat. Waktu generasi (pembelahan sel menjadi dua kali lipat) setiap sel berbeda-beda. Golongan Coli memerlukan waktu $\pm 20-25$ menit (Muslimin, 1995). Tindakan bakteri aerobik pada sumber makanan sering menurunkan oksigen terlarut sampai nol. Jika ini terjadi, proses penguraian diambil alih oleh organisme anaerobik yang menghasilkan gas methan dan hidrogen sulfida (Sastrawijaya, 2000).

Pengolahan anaerobik adalah sistem yang pengolahannya dijalankan di sebuah tempat yang kekurangan oksigen dan tidak mempunyai banyak variasi seperti pada sistem aerobik.
Sistem ini efektif untuk pengolahan cairan limbah yang kental, dan ini sering digunakan sebagai langkah awal untuk mengurangi zat organik yang kemudian diikuti dengan pengolahan aerobik (Sunu, 2001).

Proses pengolahan anaerobik yaitu proses pengolahan air yang menggunakan organisme yang aktif dimana oksigen tidak ada, dan proses ini mungkin ditunjukkan oleh proses fermentasi metan. Sebagai hasil fermentasi metan oleh bakteri anaerobik, zat organik yang komplek seperti karbohidrat, lemak dan protein mengalami proses dekomposisi/pembusukan ke dalam metan $\left(\mathrm{CH}_{4}\right)$ dan karbon dioksida $\left(\mathrm{CO}_{2}\right)$. Proses pengolahan anaerobik biasanya digunakan untuk mengolah air limbah yang konsentrasinya tinggi atau lumpur. Pada umumnya air limbah yang diproses dengan pengolahan anaerobik dilanjutkan dengan pengolahan aerobik (Sunu, 2001).

Sistem ini memiliki organisme yang menempel pada zat padat dan mengolah air melalui kontak dengan air limbah yang biasanya disebut metode biofilm. Proses biofilm merupakan proses untuk menjernihkan air dengan membiarkan mikroorganisme yang menempel di potongan lumut pada permukaan beberapa bahan dasar, kemudian menghubungkannya dengan air tercemar. Proses biofilm ini mempunyai karakteristik yaitu bahwa operasi ini relatif lebih sederhana dan mudah karena tidak ada pembesaran lumpur dan jumlah kelebihan generasi Lumpur relatif kecil (Sunu, 2001). Efektivitas bioafilter anaerob aerob sangat dipengaruhi oleh debit aliran (Flow Rate), Waktu detensi (Detention Time) dan konsentrasi kepekatan limbah cair masukan (influent).

\section{Metode}

Penelitian ini eksperimen atau percobaan (experiment resesrch) adalah kegiatan percobaan (experiment), yang bertujuan untuk mengetahui suatu gejala atau pengaruh yang timbul, sebagai akibat dari adanya perlakuan tertentu, pengaruh variabel penelitian, yaitu Kapasitas aliran/debit (Q), waktu tinggal (detention time), terhadap media biofilter anaerob aerob dalam menurunkan kadar BOD, COD, TSS dan Coliform limbah cair rumah sakit, lebih kecil/sama dengan standar baku mutu limbah cair dengan persentasi $\geq 80 \%$. 


\section{Hasil}

Tabel 1. Rerata Kadar BOD Limbah Cair Rumah Sakit Sebelum dan Sesudah Pengolahan dengan Biofilter Anaerob Aerob.

\begin{tabular}{ccccccc}
\hline \multirow{2}{*}{ Desain } & Kapasitas & Waktu Detensi & \multicolumn{2}{c}{ BOD (Mg/l) } & \multirow{2}{*}{ Selisih } & \multirow{2}{*}{ Penurunan (\%) } \\
& Aliran (1/jam) & $($ jam $)$ & Sebelum & Sesudah & & 71,15 \\
\multirow{2}{*}{ A } & 30 & 6 & 60,65 & 17,5 & 43,15 & 63,07 \\
& 60 & 3 & 60,65 & 22,4 & 38,25 & 69,99 \\
B & 30 & 6 & 60,65 & 18,2 & 42,45 & 63,23 \\
& 60 & 3 & 60,65 & 22,3 & 38,35 & 73,29 \\
C & 30 & 6 & 60,65 & 16,2 & 44,45 & 66,20 \\
& 60 & 3 & 60,65 & 20,5 & 40,15 & \\
\cline { 2 - 6 }
\end{tabular}

Tabel 2. Rerata Kadar COD Limbah Cair Rumah Sakit Sebelum dan Sesudah Pengolahan dengan Biofilter Anaerob Aerob.

\begin{tabular}{ccccccc}
\hline \multirow{2}{*}{ Desain } & $\begin{array}{c}\text { Kapasitas } \\
\text { Aliran (1/jam) }\end{array}$ & \multirow{2}{*}{$\begin{array}{c}\text { Waktu Detensi } \\
\text { (jam) }\end{array}$} & \multicolumn{2}{c}{ COD (Mg/l) } & \multirow{2}{*}{ Selisih } & \multirow{2}{*}{ Penurunan (\%) } \\
\cline { 4 - 5 } A & 30 & 6 & 620 & 184 & 436 & 70,32 \\
& 60 & 3 & 620 & 310 & 310 & 50,00 \\
B & 30 & 6 & 620 & 256 & 364 & 58,71 \\
& 60 & 3 & 620 & 288 & 332 & 53,55 \\
C & 30 & 6 & 620 & 143 & 477 & 76,94 \\
& 60 & 3 & 620 & 185 & 435 & 70,16 \\
\hline
\end{tabular}

Tabel 3. Rerata Kadar TSS Limbah Cair Rumah Sakit Sebelum dan Sesudah Pengolahan dengan Biofilter Anaerob Aerob.

\begin{tabular}{|c|c|c|c|c|c|c|}
\hline \multirow{2}{*}{ Desain } & \multirow{2}{*}{$\begin{array}{c}\text { Kapasitas Aliran } \\
\text { (1/jam) }\end{array}$} & \multirow{2}{*}{$\begin{array}{l}\text { Waktu Detensi } \\
\text { (jam) }\end{array}$} & \multicolumn{2}{|c|}{$\mathrm{TSS}(\mathrm{Mg} / \mathrm{l})$} & \multirow{2}{*}{ Selisih } & \multirow{2}{*}{ Penurunan $(\%)$} \\
\hline & & & Sebelum & Sesudah & & \\
\hline \multirow{2}{*}{ A } & 30 & 6 & 47 & 13 & 34 & 72,34 \\
\hline & 60 & 3 & 47 & 16 & 31 & 65,96 \\
\hline \multirow{2}{*}{ B } & 30 & 6 & 47 & 14 & 33 & 70,21 \\
\hline & 60 & 3 & 47 & 18 & 29 & 61,70 \\
\hline \multirow{2}{*}{ C } & 30 & 6 & 47 & 11 & 36 & 76,60 \\
\hline & 60 & 3 & 47 & 13 & 34 & 72,34 \\
\hline
\end{tabular}

Tabel 4. Rerata MPN Coliform Limbah Cair Rumah Sakit Sebelum dan Sesudah Pengolahan dengan Biofilter Anaerob Aerob.

\begin{tabular}{ccccccc}
\hline \multirow{2}{*}{ Desain } & $\begin{array}{c}\text { Kapasitas Aliran } \\
(1 / \text { jam })\end{array}$ & $\begin{array}{c}\text { Waktu Detensi } \\
(\text { jam })\end{array}$ & \multicolumn{2}{c}{ MPN Coliform } & Selisih & Penurunan $(\%)$ \\
\cline { 4 - 5 } & 30 & 6 & Sebelum & Sesudah & & \\
A & 60 & 3 & 9.300 & 2200 & 7100 & 76,34 \\
& 30 & 6 & 9.300 & 2350 & 6950 & 74,73 \\
B & 60 & 3 & 9.300 & 2300 & 7000 & 75,27 \\
& 30 & 6 & 9.300 & 2400 & 6900 & 74,19 \\
C & 60 & 3 & 9.300 & 1500 & 7800 & 83,87 \\
& & 6 & 9.300 & 2300 & 7000 & 75,27 \\
\hline
\end{tabular}


Tabel 5. Hasil Uji Statistik Perbedaan Kadar BOD, COD, TSS dan Coliform sebelum dan sesudah Pengolahan Biofiler Anaerob Aerob

\begin{tabular}{lrrrrrr}
\hline \multirow{2}{*}{ Parameter } & \multirow{2}{*}{$\mathrm{t}$} & $\mathrm{df}$ & Sig. (2-tailed) & \multirow{2}{*}{$\begin{array}{c}\text { Mean } \\
\text { Difference }\end{array}$} & \multicolumn{2}{c}{ 95\% Confidence Interval of the } \\
\cline { 6 - 7 } & & & & & Difference & \\
\hline BOD & 18,379 & 5 & 0,000 & 19,52 & 16,79 & Upper \\
COD & 8,385 & 5 & 0,000 & 227,67 & 157,87 & 22,25 \\
TSS & 13,974 & 5 & 0,000 & 14,17 & 11,56 & 16,77 \\
COLIFORM & 15,796 & 5 & 0,000 & 2175,00 & 1821,06 & 2528,94 \\
\hline
\end{tabular}

\section{Pembahasan}

\section{Biological Oxygent Demand (BOD)}

Biological Oxygent Demand (BOD) merupakan indikator kebutuhan oksigen untuk oksidasi biologis zat organik. Semakin tinggi kadar BOD dalam limbah cair, semakin rendah jumlah mikrobia aerob dan fakultatif aerob yang berada dalam limbah cair. Jika dibandingkan dengan kadar BOD sebelum pengolahan, ternyata kadar BOD pada kapasitas aliran 30 1/jam, waktu detensi 6 jam relatif lebih kecil. Kondisi tersebut mempengaruhi aktifitas mikroba dalam proses dekomposisi karena kurangnya nutrisi sehingga penurunan kadar BOD tidak optimal. Sebaliknya pada kapasitas aliran 30 1/jam, waktu detensi 6 jam, disebabkan karena kadar BOD sebelum pengolahan relatif lebih tinggi sehingga proses dekomposisi bahan organik lebih optimal karena tersedia cukup nutrisi yang memungkinkan perkembangbiakan bakteri lebih cepat. Dengan demikian dapat dikatakan bahwa pengolahan limbah cair rumah sakit dengan biofilter anaerob aerob belum efektif menurunkan kadar BOD. Hal ini karena waktu detensi dalam penelitian ini yakni 6 jam.

Penurunan kadar BOD terjadi pada filter anaerobik dimana pada situasi mikrobia anaerobik yang tumbuh pada media batu berperan sebagai pengurai zat organik di dalam limbah cair saat melewati filter anaerobik tersebut. Saat masuk ke dalam biofilter anaerob aerob pada proses anaerob mikroorganisme aerob masih hidup karena kandungan oksigen dalam air limbah masih ada, tetapi kemudian mati karena kehabisan oksigen. Dengan kematian mikroorganisme aerob maka proses penguraian diambil alih oleh mikroorganisme anaerob. Pada filter anaerobik limbah cair akan melewati media filter yang dilapisi oleh film yang merupakan koloni mikrobia anaerob, saat melewati media ini zat organik tertahan oleh filter dan akan didegrasai oleh mikrobia yang menempel pada filter tersebut (Jenie dan Rahayu, 1993), sehingga jumlahnya semakin berkurang (dengan berkurangnya jumlah zat organik di dalam limbah cair tersebut menyebabkan kadar BOD turun).

Proses pengolahan anaerobik menggunakan organisme yang aktif dimana oksigen tidak ada, dan proses ini ditunjukkan oleh proses fermentasi metan. Sebagai hasil fermentasi metan oleh bakteri anaerobik, zat organik yang komplek seperti karbohidrat, lemak dan protein mengalami proses dekomposisi/pembusukan ke dalam metan $\left(\mathrm{CH}_{4}\right)$ dan karbon dioksida $\left(\mathrm{CO}_{2}\right)$. Hal ini dipengaruhi oleh kerja enzim yang disintetiskan oleh sel-selnya, karena setiap enzim memiliki lapisan yang spesifik yang bekerja pada lapisan itu sendiri (bahan organik). Dengan demikian teori yang dikemukakan oleh Sunu 2001, yang mengatakan bahwa pengolahan dengan filter anaerobik efektif untuk pengolahan cairan limbah yang kental, dan ini sering digunakan sebagai langkah awal untuk mengurangi zat organik, terbukti.

Penurunan BOD selanjutnya terjadi pada filter aerobik. Sistem ini memiliki organisme yang menempel pada zat padat dan mengolah air melalui kontak dengan air limbah yang biasanya sering disebut metode biofilm. Proses biofilm ini mempunyai karakteristik yaitu bahwa operasi ini relatif lebih sederhana dan mudah karena tidak ada pembesaran lumpur dan jumlah kelebihan generasi Lumpur relatif kecil (Sunu, 2001).

Pengolahan sekunder (biologis) dengan biofilter anaerob aerob mampu menurunkan kadar BOD antara 63,07\%-73,29\% yang berarti bahwa kemampuan (Efisiensi) biofilter anaerob 
aerob dalam menurunkan kadar BOD tergolong sedang Hasil penelitian ini lebih tinggi dari temuan Wimbadi (2002) dengan modifikasi septic tank dapat menurunkan BOD sebesar 23\%-77\%, Dari Tabel 1 diketahui bahwa dengan kapasitas aliran dan waktu detensi yang bervariasi, rata-rata persentase penurunan kadar BOD sebelum dan sesudah pengolahan dengan Biofilter Anaerob Aerob lebih dari 70\%, yang berarti bahwa Biofilter Anaerob Aerob cukup efektif dalam menurunkan kadar BOD limbah cair rumah sakit.

\section{Chemical Oxygent Demand (COD)}

Chemical Oxygent Demand (COD) merupakan indikator kebutuhan oksigen kimia untuk oksidasi biologis zat organik atau dapat dikatakan bahwa semakin tinggi kadar COD dalam limbah cair, semakin rendah jumlah mikrobia aerob dan fakultatif aerob yang berada dalam limbah cair. Secara keseluruhan pengolahan dengan biofilter anaerob aerob telah mampu menurunkan kadar COD lebih kecil dari baku mutu limbah cair untuk kegiatan rumah sakit yaiatu $80 \mathrm{mg} / \mathrm{l}$ (KEP-58/MENLH/12/1995). Dengan demikian dapat dikatakan bahwa pengolahan limbah cair rumah sakit dengan Biofilter Anaerob Aerob efektif menurunkan kadar COD.

Pada Tabel 2 diketahui bahwa setelah limbah cair dialirkan, Biofilter Anaerob Aerob mampu menurunkan kadar COD berkisar antara 50,00\%-76,94\%, hal ini berarti kadar COD limbah cair mengalami penurunan. Penurunan kadar COD di dalam limbah cair dimulai sejak air limbah dimasukkan kedalam bak equalisasi karena pengendapan patikel-patikel zat organik tersuspensi. Adanya pengendapan tersebut terbukti dengan adanya endapan lumpur didasar wadah. Dengan semakin mengendapnya zat organik tersebut menyebabkan kebutuhan oksigen untuk mendegradasi zat organik secara kimia berkurang.

Proses penurunan COD pada Biofilter Anaerob Aerob tersebut berlangsung sejak limbah cair berada dalam bak equalisasi karena adanya pengendapan partikel-partikel zat organik tersuspensi, tidak stabil dan yang relatif besar secara grafitasi di dasar bak. Dengan mengendapnya sebagian zat organik, menyebabkan kebutuhan oksigen untuk oksidasi zat organik berkurang. Selanjutnya penurunan kadar COD terjadi pada filter anaerobik dan filter aerobik. Hal ini disebabkan karena zat organik di dalam limbah cair akan dioksidasi oleh hadirnya katalisator Kalium bickromat menjadi gas $\mathrm{CO}_{2}$ dan $\mathrm{H}_{2} \mathrm{O}$ sehingga kadar zat organic di dalam limbah cair mengalami penurunan.

Saat air limbah dialirkan dengan debit 30 liter/jam, dan 60 liter/jam, Biofilter Anaerob Aerob mampu menurunkan kadar COD dengan efisiensi berkisar antara 50,00\%-76,94\%.

\section{Total Suspended Solid (TSS)}

Total Suspended Solid (TSS) adalah salah satu parameter kualitas limbah cair yang menyatakan besar kecilnya tingkat pencemaran tehadap limbah cair. Makin tinggi nilai TSS, makin tinggi tingkat pencemaran suatu perairan (Manik, 2003). Padatan tersuspensi dalam limbah cair umumnya terdiri dari fitoplankton, zooplankton, kotoran manusia, kotoran hewan, lumpur, sisa tanaman dan hewan, dan limbah cair. Tidak terdapat perbedaan bermakna antara variasi kapasitas aliran (debit) 30 1/jam, dan 60 1/jam dan waktu detensi 6 jam dan 3 jam, terhadap persentase penurunan kadar TSS limbah cair rumah sakit sebelum dan sesudah pengolahan. Efisiensi penurunan kadar TSS tertinggi pada kapasitas aliran 30 1/jam dan waktu detensi 6 jam $(76,60 \%)$ disebabkan karena kadar TSS sebelum pengolahan relatif lebih kecil dimana pada kondisi ini memungkinkan proses degradasi padatan tersuspensi lebih optimal. Secara keseluruhan pengolahan dengan biofilter anaerob aerob telah mampu menurunkan kadar TSS lebih kecil dari baku mutu limbah cair untuk kegiatan rumah sakit yaiatu $30 \mathrm{mg} / \mathrm{l}$ (KEP58/MENLH/12/1995). Dengan demikian dapat dikatakan bahwa pengolahan limbah cair rumah sakit dengan Biofilter Anaerob Aerob efektif menurunkan kadar TSS.

Proses penurunan TSS pada biofilter anaerob aerob tersebut terjadi pada filter anaerobik-anaerobik dimana mikrobia yang tumbuh pada media filter anaerobik-aerobik berperan sebagai pengurai zat organik tersuspensi di dalam limbah cair saat melewati filter tersebut. Degradasi zat organik tersuspensi secara anaerob dan bakteri anaerob menghasilkan $\mathrm{NH}_{3}, \mathrm{CH}_{4}$ dan $\mathrm{H}_{2} \mathrm{~S}$. Degradasi tersebut menyebabkan turunnya kadar zat organik tersuspensi (TSS). 


\section{MPN Coliform}

Setiap badan air tidak terlepas dari adanya bakteri patogen baik yang berasal dari kotoran manusia maupun kotoran hewan dan dari tanah. MPN Coliform merupakan ukuran banyaknya jumlah Coliform total di dalam limbah cair.

Penurunan MPN Coliform limbah cair rumah sakit seperti pada tabel 6 menunjukkan bahwa kemampuan (efisiensi) Biofilter Anaerob Aerob tidak dipengaruhi oleh kapasitas aliran (debit) maupun waktu detensi. Tidak terdapat perbedaan yang mencolok antara variasi kapasitas aliran (debit) dan waktu detensi terhadap persentase penurunan MPN Coliform limbah cair rumah sakit sebelum dan sesudah pengolahan, akan tetapi terdapat kecenderungan bahwa semakin besar kapasitas aliran dan semakin cepat waktu detensi, semakin kecil persentase penurunan kadar MPN Coliform yang berarti Biofilter Anaerob Aerob efektif menurunkan MPN Coliform pada kapasitas aliran yang lebih kecil dan waktu detensi yang lebih lama. MPN Coliform di dalam limbah cair rumah sakit sebelum pengolahan lebih kecil dari baku mutu limbah cair untuk kegiatan rumah sakit yaitu 10.000/100 ml limbah cair (KEP58/MENLH/12/1995), dapat digambarkan bahwa secara keseluruhan pengolahan limbah cair rumah sakit dengan Biofilter Anaerob Aerob dapat menurunkan MPN Coliform.

\section{Kesimpulan}

Desain media biofilter anaerob aerob dengan media botol kemasan air mineral $330 \mathrm{ml}$ kapasitas aliran 0,5 liter/menit waktu detensi 6 jam lebih efektif dibandingkan dengan media botol kemasan air mineral $600 \mathrm{ml}$ dan gelas kemasan air mineral $200 \mathrm{ml}$.

\section{Saran}

Perlu penelitian lanjutan untuk mengetahui hubungan waktu detensi, kapasitas aliran terhadap efektifitas media biofiltrasi.

\section{Daftar Pustaka}

Depkes, RI., 2004, Pedoman Sanitasi Rumah Sakit, Depkes RI, Jakarta.

Jenie B.S. dan Rahayu W.P., 1993. Penanganan Limbah Industri Pangan, Kanisius, Yogyakarta.

Muslimin, W. L., $1995 . \quad$ Mikrobiologi Lingkungan, Direktorat Jenderal Pendidikan Tinggi, Jakarta.

Nainggolan, N., 2003. Limbah Klinis Menurunkan Kualitas Air Tanah http// www.yahoo.com.10 Desember 2003.

Sastrawijaya, A.T., 2000. Pencemaran Lingkungan, Rineka Cipta, Jakarta.

Soedjarwo, 2003. Pengolahan Limbah Cair Domestik, Rumah Sakit dan Hotel, Pelatihan Dasar Teknologi Tepat Guna Pengolahan Limbah Cair, Pusteklim, Yogyakarta, 8-19 Desember 2003.

Sunu, P., 2001. Melindungi Lingkungan dengan Menerapkan ISO 14001, Gramedia Widasarana Indonesia, Jakarta.

Supardi, H. I., 2003. Lingkungan Hidup dan Kelestariannya, Alumni, Bandung.

Suriawiria, U., 2003. Mikrobiologi Air, Alumni, Bandung.

Suryanto, 2003. Rumah Sakit Pertamina Gunakan IPAL Dewats//www.yahoo.com 27 Oktober 2003.

Wardhana, W. A., 2001. Dampak Pencemaran Lingkungan, Andi Yogyakarta. 